\title{
MAGMA GENERATION AND MIXING IN THE EARLIEST VOLCANIC CENTRE OF SANTORINI (AKROTIRI PENINSULA). MINERAL CHEMISTRY EVIDENCE FROM THE AKROTIRI PYROCLASTICS
}

\author{
Kitsopoulos K. \\ University of Leicester, Department of Geology, University Road, LE1 7RH Leicester, UK, \\ kitsopoulos.k@gmail.com
}

\begin{abstract}
Santorini is a dominant expression of magma generation and subsequent volcanism in the Meditereanean area, where a calk-alkaline, high-alumina, basalt-andesite-dacite type of volcanism was expressed from eight centres. The volcanics of the Akrotiri peninsula are considered to be the products of the earliest (Pliocene-Pleistocene) volcanic centre. The present study has investigated the mineral chemistry of some major pyrogenic phenocrysts, such as plagioclase and Fe-Ti oxides, of the Akrotiri pyroclatics unit, which have undergone a notable zeolitization procedure. The results are compatible with magma mixing mechanism of a primitive mantle derived, saturated, of mafic composition component with silicic magma in shallow crustal depths.
\end{abstract}

Key words: pyroclastics, plagioclase, Fe-Ti oxides, mineral chemistry, magma mixing, Santorini, Greece.

\section{Introduction}

The petrographic and volcanological characterisitics of volcaniclastic material are often thoroughly studied in terms of revealing the magma's physical properties, eruption mechanisms and deposition conditions. On the other hand, detailed petrological studies of such type of materials, for example mineral chemistry of the phases present, are not so usual. Furthermore, in cases where those volcaniclastic materials are thought to have gone under a series of alteration procedures, starting from low grade transformations, such as clay and zeolite alteration, to heavy hydrothermal alteration, then these materials are usually overlooked. However, the knowledge of the chemical composition of the pyrogenic mineral phases present, even in altered pyroclastic materials, could lead to notable conclusions regarding the magma evolution and petrogenetic procedures.

Santorini is situated in the centre of the prominent of the South Aegean Volcanic Arc. Evidence of the influence of the activity of the Arc are widespread in the eastern Mediterranean area. Bathrellos et al. (2009) have studied a pumice pebbles-rich sandy horizon, located in Holocene deposits of western Peloponnesus and they suggested tan origin for the pumice in the South Aegean Volcanic Arc. It is implied that they related to a paroxysmal event of the arc, floated on the sea and they arrived though the combined action of wind and marine currents.

In Santorini, Greece, the volcanic rocks are the product of a calk-alkaline, high-alumina, basalt-andesite-dacite type of volcanism, which was expressed from eight centres (Pichler and Kussmaul, 1972). The majority of the volcanics around the Akrotiri peninsula of Santorini are considered to be 


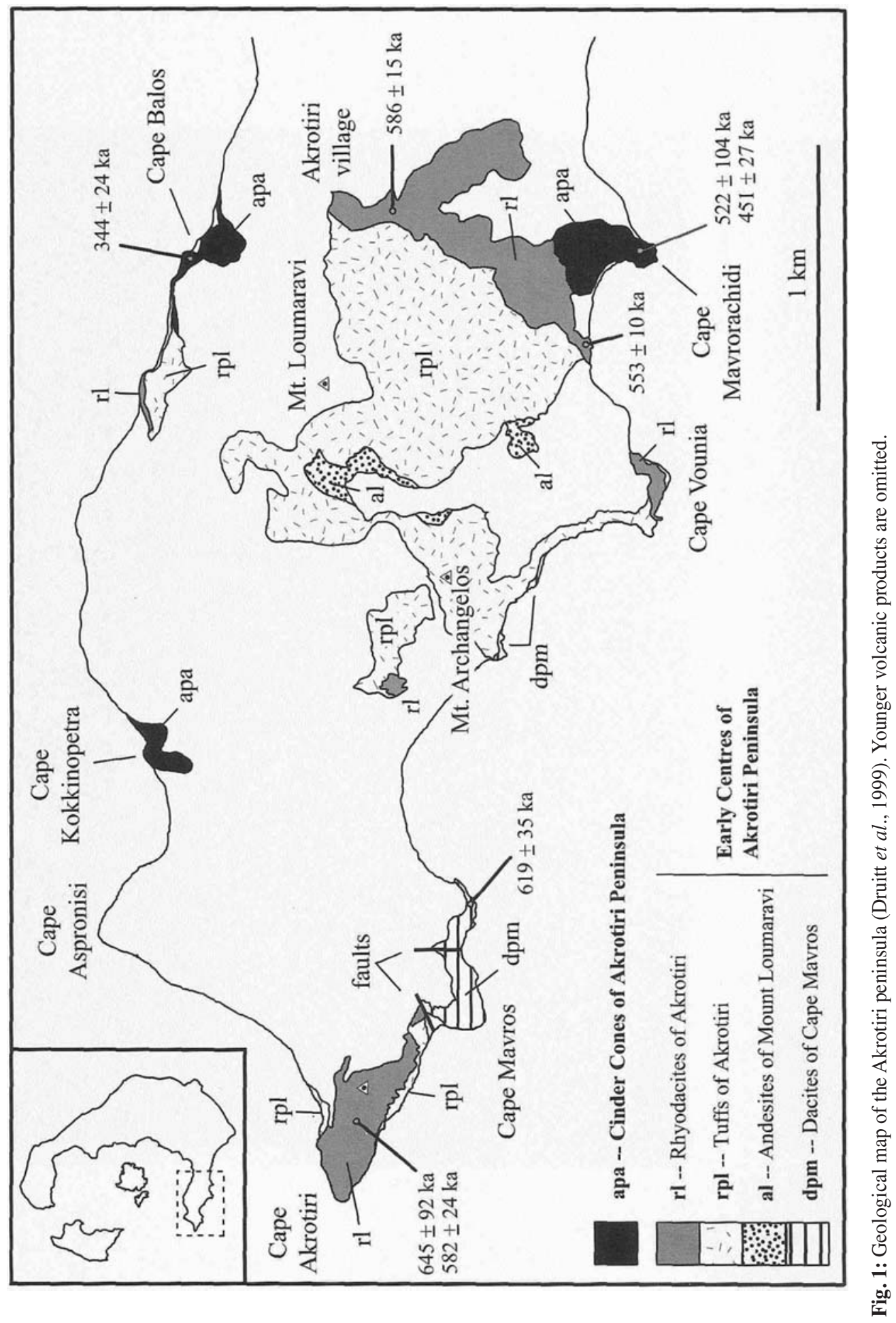


the first volcanic products in Santorini, with an age of Pliocene to Pleistocene. In this area a predominant feature is a pyroclastic unit, consisting of tuffs, breccias and conglomerates. The mineralogy of the material throughout the outcrop is dominated by zeolite minerals (Tsolis-Katagas and Katagas, 1989 and Kitsopoulos, 1995, 1996).

The present study has examined the mineral chemistry of the major pyrogenic phenocrysts of the Akrotiri pyroclatics unit., with the aim to contribute to the knowledge of magma generation mechanisms in the earliest known eruption period of Santorini Volcano.

\section{Geological setting}

The three islands of Santorini (Thera) (Santorini), Therasia and Aspronisi are the remnants of the Santorini stratocone, while the Old and New Kameni are the products of a much later volcanism.

The complete evolution of the Santorini volcanic complex has been studied by Druitt et al. (1999), while Nichols (1971) and Huijsmans et al. (1988) focused mostly on the younger volcanic products. The majority of the volcanics around the Akrotiri peninsula are considered to be the first volcanic products in Santorini (Pliocene-Pleistocene). They have been studied by Davis et al.(1998) and Dietrich et al. (1998). The geology of the Akrotiri Peninsula is given in Figure 1. Two volcanic suites have been recognised; the silicic Lumaravi-Archangelos and the mafic Akrotiri volcanic suites.

The Lumaravi-Archangelos volcanic suite is composed of submarine domes, coulees, and hyaloclastite aprons (Rhyodacites of Akrotiri, rl in Figure 1) intercalating with vitric tuffs, pumice breccias and conglomerates (Tuffs of Akrotiri, rpl in Figure 1).

The pyroclastic materials are the expression of three different centres. The white to pale green tuffs originally consisted of ash and/or lapilli, which were vitric and crystalline in composition. Agglomerated bands consisting of gray to green dacitic cognate xenoliths up to $15 \mathrm{~cm}$ long form tuff breccia. The exposed thickness is about $160 \mathrm{~m}$ but some borehole investigations recorded at least 220 $\mathrm{m}$. Fouque (1879) found Pliocene marine fossils indicating deposition in shallow water, although no evidence of sorting was reported by him. The mafic Akrotiri volcanic suite is composed of small domes and flows of andesites and basalts.

\section{Materials and Methods}

\subsection{Akrotiri pre-Caldera Zeolitized Pyroclastics}

The samples used in this study were collected from the "Tuffs of Akrotiri" unit of Figure 1, which has undergone substantial zeolitization.

The zeolitization of the pyroclastics involved the development of heulandite type of minerals and illite/smectite which have replaced the vitric matrix, forming characteristic pseudomorphs after the inner parts of glass shards. Authigenic opal-CT and cristobalite, halite, and pyrogenic phenocrysts of feldspars, amphiboles and Fe-Ti oxides complete the mineralogy. By using thermal tests the heulandite type of minerals were classified as heulandites type 3, i.e. clinoptilolites.

Tsolis-Katagas and Katagas (1989) proposed that the formation of zeolites resulted from the activity of interstitial water into the pile of the volcaniclastic material. The different mineralogical assemblages and compositions were attributed by the same authors to variations in the heat flow, the ionic activity in the interstitial waters, and the permeability. Kitsopoulos (1996) suggested that the formation of heulandite type of minerals did not exactly follow a "glass dissolution" path, but it involved 
a number of continuous reactions. These reactions and their subsequent results were often controlled in numerous small closed sub-systems, even within the area of individual glass particles. The formation of zeolites did not proceed through a form of complete dissolution, but a continuous two endmembers equilibrium reaction between the solid and the fluid components of a rather closed system.

The silicic pyroclastics range in $\mathrm{SiO}_{2}$ from $61-75 \%$, with a mean value of $67.2 \%$, therefore, they could be classified as rhyodacites-dacites to low-Si rhyolites (Kitsopoulos, 1995). Because of the zeolitization process that the pyroclastics had undergone, the trace element discrimination diagram $\mathrm{Nb} / \mathrm{Y}$ vs. Zr/TiO2, proposed by Winchester and Floyd (1977), were also applied on the Akrotiri zeolitized pyroclastics. Kitsopoulos et. al.,(2001) concluded, that the formation of the zeolites should have been mainly facilitated by an acidic precursor, obviously a rhyodacite-dacite type of rock. A small number of the samples used plotted very close to the rhyodacite-dacite/andesite boundary and one in the andesite field, indicating a more basic origin of their precursor. It was also found that there was no change in the alkaline affinity recorded during the eruption of the Akrotiri tuffs, but at the same time some degree of magma differentiation was evidenced.

\subsection{Electron MicroProbe Analysis (EMPA)}

EMPA was used to study the composition of the major mineral phases, other than the zeolite minerals, in the zeolitized tuffs. Carbon-coated polished thin sections were prepared from impregnated samples. The instrument used was a JEOL JXA-8600 Superprobe. The specific probe model carries four wavelength spectrometers (WDS) and is also equipped with a LINK 860 Series 1 Energy Dispersive System (EDS) detector with a $158 \mathrm{eV}$ resolution at $5.8 \mathrm{KeV}$, which is used to analyse crystals with high volatility, and of very small sizes. The beam for the WDS analyses was operated at $15 \mathrm{kV}$ and $30 \mathrm{nA}$, voltage and current conditions. Wollastonite was used for the standardisation of $\mathrm{Si}$ and $\mathrm{Ca}$, rutile for $\mathrm{Ti}$, jadeite for $\mathrm{Al}$ and $\mathrm{Na}, \mathrm{Fe} 3 \mathrm{O} 4$ for Fe, rhodonite for $\mathrm{Mn}, \mathrm{MgO}$ for $\mathrm{Mg}, \mathrm{CH} 14$ (microcline) for $\mathrm{K}$ and pure $\mathrm{Cr}$ and $\mathrm{Ni}$ for $\mathrm{Cr}$ and $\mathrm{Ni}$ respectively. All the running conditions, crystals and the values of standard used are described in detail by Kitsopoulos (1995) and they are available in the microprobe laboratory of Geology Department of Leicester University, UK.

\section{Data}

\subsection{Data}

More than 600 analyses were taken from plagioclase crystals from the Akrotiri pyroclastics, Some representative analyses are given in Table 1.

Some representative analysis of Fe-Ti oxides are given in Table 2. The analyses are recalculated to allow any $\mathrm{Fe}^{+3}$ to be distributed. The magnetite analysis which are given were the best results which could be achieved and they are taken into account, albeit the consideration of having low totals and therefore not to be perfectly reliable for interpretation.

\section{Discussion - Conclusions}

The majority of the plagioclases from the Akrotiri pyroclastics unit are falling within the region of andesine to labradorite with just a few crystals falling to the oligoclase composition. The plagioclases seem to exhibit a rather intermediate composition in contrast with the overall acidic geochemistry of the samples. The Or content in the plagioclases reach values up to $10-12 \%$ and in some cases the percentage is even higher and it can go up to $20-30 \%$. Since a notable number of the analyses consider analyses of crystals' rims, the fact suggests that some of the crystals apparently have a rim of 
Table 1.

\begin{tabular}{|c|c|c|c|c|c|}
\hline $\mathrm{SiO}_{2}$ & 56.59 & 56.61 & 54.22 & 58.24 & 43.69 \\
\hline $\mathrm{TiO}_{2}$ & 0.02 & 0.01 & 0.02 & 0.01 & 0.04 \\
\hline $\mathrm{Al}_{2} \mathrm{O}_{3}$ & 27.07 & 26.80 & 27.70 & 24.94 & 34.70 \\
\hline $\mathrm{FeO}$ & 0.28 & 0.36 & 0.36 & 0.36 & 0.30 \\
\hline $\mathrm{MnO}$ & 0.01 & 0.01 & 0.02 & 0.05 & 0.03 \\
\hline $\mathrm{MgO}$ & 0.01 & 0.02 & 0.04 & 0.01 & 0.10 \\
\hline $\mathrm{CaO}$ & 9.66 & 9.38 & 11.08 & 7.88 & 19.77 \\
\hline $\mathrm{Na}_{2} \mathrm{O}$ & 6.11 & 6.17 & 5.28 & 5.56 & 0.59 \\
\hline $\mathrm{K}_{2} \mathrm{O}$ & 0.21 & 0.23 & 0.17 & 2.05 & 0.03 \\
\hline Total & 100.15 & 99.77 & 99.22 & 99.21 & 99.38 \\
\hline $\mathrm{Si}$ & 10.183 & 10.222 & 9.911 & 10.581 & 8.173 \\
\hline $\mathrm{Ti}$ & 0.003 & 0.001 & 0.003 & 0.001 & 0.006 \\
\hline $\mathrm{Al}$ & 5.742 & 5.704 & 5.968 & 5.341 & 7.651 \\
\hline $\mathrm{Fe}^{+2}$ & 0.042 & 0.054 & 0.055 & 0.055 & 0.047 \\
\hline $\mathrm{Mn}$ & 0.002 & 0.002 & 0.003 & 0.008 & 0.005 \\
\hline $\mathrm{Mg}$ & 0.003 & 0.005 & 0.011 & 0.003 & 0.028 \\
\hline $\mathrm{Ca}$ & 1.863 & 1.815 & 2.170 & 1.534 & 3.963 \\
\hline $\mathrm{Na}$ & 2.132 & 2.160 & 1.871 & 1.959 & 0.214 \\
\hline $\mathrm{K}$ & 0.048 & 0.053 & 0.04 & 0.475 & 0.007 \\
\hline $\mathrm{An}$ & 46.072 & 45.054 & 53.174 & 38.661 & 94.713 \\
\hline$\overline{A b}$ & 52.734 & 53.360 & 45.854 & 49.363 & 51.150 \\
\hline Or & 11.925 & 13.154 & 0.9714 & 11.975 & 0.1711 \\
\hline cations & 20.034 & 20.031 & 20.058 & 19.964 & 20.106 \\
\hline oxygens & 32.000 & 32.000 & 32.000 & 32.000 & 32.000 \\
\hline
\end{tabular}

Table 2.

\begin{tabular}{|l|c|c|c|c|c|}
\hline & \multicolumn{5}{|c|}{ Ilmenite analyses } \\
\hline $\mathrm{SiO}_{2}$ & 0.00 & 0.00 & 0.00 & 0.00 & 0.03 \\
\hline $\mathrm{TiO}_{2}$ & 38.94 & 40.11 & 40.07 & 38.90 & 37.99 \\
\hline $\mathrm{Al}_{2} \mathrm{O}_{3}$ & 0.27 & 0.22 & 0.25 & 0.32 & 0.28 \\
\hline $\mathrm{Cr}_{2} \mathrm{O}_{3}$ & 0.03 & 0.04 & 0.02 & 0.01 & 0.03 \\
\hline $\mathrm{V}_{2} \mathrm{O}_{3}$ & 0.03 & 0.02 & 0.09 & 0.18 & 0.08 \\
\hline $\mathrm{FeO}$ & 30.08 & 30.83 & 30.63 & 29.52 & 29.15 \\
\hline $\mathrm{Fe}_{2} \mathrm{O}_{3}$ & 27.11 & 24.60 & 26.56 & 27.07 & 28.76 \\
\hline $\mathrm{MnO}$ & 0.83 & 0.86 & 0.82 & 0.70 & 0.82 \\
\hline $\mathrm{MgO}$ & 2.21 & 2.41 & 2.49 & 2.62 & 2.32 \\
\hline $\mathrm{CaO}$ & 0.01 & 0.01 & 0.01 & 0.01 & 0.02 \\
\hline $\mathrm{NiO}$ & 0.03 & 0.02 & 0.02 & 0.03 & 0.03 \\
\hline
\end{tabular}


Table 2 (continued).

\begin{tabular}{|l|c|c|c|c|c|}
\hline & \multicolumn{5}{|c|}{ Ilmenite analyses } \\
\hline $\mathrm{ZnO}$ & 0.13 & 0.02 & 0.11 & 0.04 & 0.03 \\
\hline $\mathrm{Total}$ & 99.67 & 99.17 & 101.07 & 99.40 & 99.54 \\
\hline & & & & & \\
\hline $\mathrm{Si}$ & 0.000 & 0.000 & 0.000 & 0.000 & 0.001 \\
\hline $\mathrm{Ti}$ & 0.740 & 0.763 & 0.749 & 0.739 & 0.722 \\
\hline $\mathrm{Cr}$ & 0.010 & 0.001 & 0.000 & 0.000 & 0.001 \\
\hline $\mathrm{Fe}^{+2}$ & 0.635 & 0.652 & 0.637 & 0.632 & 0.616 \\
\hline $\mathrm{Fe}^{+3}$ & 0.515 & 0.468 & 0.497 & 0.514 & 0.547 \\
\hline $\mathrm{Mn}$ & 0.018 & 0.018 & 0.017 & 0.015 & 0.018 \\
\hline $\mathrm{Mg}$ & 0.083 & 0.091 & 0.092 & 0.099 & 0.087 \\
\hline $\mathrm{Ca}$ & 0.000 & 0.000 & 0.000 & 0.000 & 0.001 \\
\hline & & & & & \\
\hline cations & 2.000 & 2.000 & 2.000 & 2.000 & 2.000 \\
\hline oxygens & 3.002 & 3.001 & 3.001 & 3.001 & 3.001 \\
\hline
\end{tabular}

\begin{tabular}{|c|c|c|c|c|c|}
\hline & \multicolumn{4}{|c|}{ Magnetite analyses } & Magnesiochromite \\
\hline$\overline{\mathrm{SiO}_{2}}$ & 0.05 & 0.00 & 0.00 & 0.03 & 0.00 \\
\hline $\mathrm{TiO}_{2}$ & 6.50 & 7.08 & 6.64 & 6.98 & 0.47 \\
\hline $\mathrm{Al}_{2} \mathrm{O}_{3}$ & 2.15 & 1.94 & 1.78 & 1.94 & 20.40 \\
\hline $\mathrm{Cr}_{2} \mathrm{O}_{3}$ & 0.04 & 0.05 & 0.07 & 0.03 & 42.17 \\
\hline $\mathrm{V}_{2} \mathrm{O}_{3}$ & 0.32 & 0.43 & 0.41 & 0.42 & 0.16 \\
\hline $\mathrm{FeO}$ & 33.00 & 33.48 & 33.88 & 33.47 & 15.65 \\
\hline $\mathrm{Fe}_{2} \mathrm{O}_{3}$ & 51.54 & 50.81 & 53.33 & 51.08 & 7.89 \\
\hline $\mathrm{MnO}$ & 0.77 & 0.83 & 0.76 & 0.76 & 0.29 \\
\hline $\mathrm{MgO}$ & 1.58 & 1.56 & 1.46 & 1.54 & 12.71 \\
\hline $\mathrm{CaO}$ & 0.02 & 0.04 & 0.03 & 0.04 & 0.00 \\
\hline $\mathrm{NiO}$ & 0.02 & 0.01 & 0.04 & 0.00 & 0.15 \\
\hline $\mathrm{ZnO}$ & 0.05 & 0.03 & 0.10 & 0.17 & 0.05 \\
\hline Total & 96.04 & 96.26 & 98.50 & 96.46 & 99.94 \\
\hline $\mathrm{Si}$ & 0.002 & 0.000 & 0.000 & 0.001 & 0.000 \\
\hline $\mathrm{Ti}$ & 0.191 & 0.208 & 0.191 & 0.205 & 0.011 \\
\hline $\mathrm{Cr}$ & 0.001 & 0.002 & 0.002 & 0.001 & 1.042 \\
\hline $\mathrm{Fe}^{+2}$ & 1.077 & 1.092 & 1.084 & 1.091 & 0.411 \\
\hline $\mathrm{Fe}^{+3}$ & 1.513 & 1.491 & 1.535 & 1.498 & 0.184 \\
\hline $\mathrm{Mn}$ & 0.025 & 0.027 & 0.025 & 0.025 & 0.008 \\
\hline $\mathrm{Mg}$ & 0.092 & 0.091 & 0.083 & 0.089 & 0.592 \\
\hline $\mathrm{Ca}$ & 0.001 & 0.002 & 0.001 & 0.002 & 0.000 \\
\hline cations & 3.001 & 3.001 & 3.001 & 3.000 & 3.000 \\
\hline oxygens & 4.000 & 4.000 & 4.000 & 4.000 & 4.000 \\
\hline
\end{tabular}


K-rich part surrounding them, indicating residual liquid rich in $\mathrm{K}$ during the crystallisation of the plagioclases.

There is no absolute clear evidence of zoning in the crystals, although techniques such as the Nomarski contrast interferometry (Anderson, 1983; Clark et al., 1986) or laser interferometry (Pearce, 1984) which can help the zoning examination were not applied. Seymour et al. (1990) for example applied these techniques in plagioclases from basalts, andsesites and dacites, which are younger than the pyroclastic deposits, from the Akrotiri area in Santorini and they concluded that three main categories of plagioclase occur. Here, wherever a positive, clear zoning was observed that was of an anorthitic core to an albitic rim.

With the exception of very few samples, where some extremely calcic plagioclase crystals with An content from An87 up to An95 were found, the overall range of An was recorded in the range $\mathrm{An}_{21}$ up to $\mathrm{An}_{72}$ which is rather wide for the single pyroclastic unit.

From the Fe-Ti oxides analyses two facies were recognised. A magnetite-ulvospinel series and a hematite-ilmenite series.

The magnetite analyses, which are presented in this study, show low totals (from 95.91 to 98.50), but they were the best analytical results could be obtained. The TiO2 values range from 6.34 to 7.55 $\%$ and despite their low totals, they represent a close relationship to the known solid solution of the magnetite-ulvospinel facies. They are poorer in Ti than those recorded by Mitropoulos and Tarney (1992) from the younger Santorini volcanics they have studied, which had a TiO2 content from 13.4 up to $17.2 \%$. Even if the assumption is made, that the amount missing to makeup the present analyses closer to 100 (an amount from 4.09 to 1.50) is all being attributed to Ti, there is still a gap between the analyses from the younger Santorini volcanics and those from Akrotiri. The titanomagnetites within the Akrotiri volcanics are clearly more oxidised than the titanomagnetites in the above volcanic sequence. These Akrotiri magnetite values are only comparable to the amount of $\mathrm{TiO} 2$ present in magnetite crystals from the western parts of the Aegean Volcanic Arc, which exhibit a TiO2 content from 4.4 up to 10.2\%. Pe-Piper and Piper (2005) have found that the western part of the arc, including Aegina, Methana, and the older rocks of Milos and Santorini, has typical arc-related andesite-dacite volcanism, predominantly of Pliocene age, associated with E-W listric faulting with slow slip rates.

The TiO2 values of the ilmenite crystals range from 37.94 to $40.80 \%$ and they represent a quite close relationship to the known solid solution of the hematite-ilmenite facies.

The hematite-ilmenite series is almost absent from studies of younger volcanics of Santorini. Mitropoulos and Tarney (1992) have recorded just one analysis of ilmenite. The $\mathrm{TiO}_{2}$ content of the analyses of the present study is $5.14 \%$ up to $8 \%$ lesser than the values recorded from the younger volcanics.

The Fe-Ti oxides analyses exhibit a positive correlation for the $\mathrm{FeO}-\mathrm{TiO}_{2}$, pair values and a negative correlation for the $\mathrm{FeO}-\mathrm{Fe}_{2} \mathrm{O}_{3}$ and $\mathrm{Fe}_{2} \mathrm{O}_{3}-\mathrm{TiO}_{2}$ pair values. For the hematite-ilmenite facies the correlation coefficients were $0.96,-0.86$ and -0.89 respectively. For the magnetite-ulvospinel facies the relevant values were: $0.69,-0.17$ and -0.72 . The lower values for this group are due probably to the poor analysis available, but this may indicate that the possible analytical problem was due to the Fe and not to Ti.

The positive correlation of $\mathrm{FeO}$ to the $\mathrm{TiO}_{2}$ and the negative corelation of the other two pairs suggests that the increase of ilmenite and possibly of ulvospinel content are related to the decrease of the $f \mathrm{O}_{2}$ within the lavas gave the Fe-Ti oxide facies. 
Karberg and Barton (2006) have calculated the $f \mathrm{O}_{2}$ values from mafic calc-alkaline magmas erupted from four volcanic centers (Akrotiri, Micro Profitis Ilias, Megalo Vouno, and Skaros) on Santorini, Greece, based on the olivine-melt equilibrium and by using microprobe analyses of olivine rims and coexisting groundmass. The $f \mathrm{O}_{2}$ lie in a fairly narrow range $(\triangle \mathrm{FMQ}=1.06 \pm 0.18)$. By combining the results with those obtained for other samples (based on mineral equilibria), have found out that the pre-eruptive oxygen fugacities of the majority of Santorini magmas (including that erupted in the well-known Minoan event) lie slightly above, but close to, values defined by the NNO buffer ( $\triangle$ FMQ $=1.13 \pm 0.26 ; \mathrm{n}=86$ ) and thus, have suggested that the redox states of mafic magmas erupted on Santorini have remained constant over $\sim 400,000$ to 600,000 years. However, they also stated that a small number of silicic lavas erupted in the Akrotiri region early in the history of the volcanic field evolved at higher $f \mathrm{O}_{2}(\Delta \mathrm{FMQ}=2.11 \pm 0.15)$.

The range of the composition of the plagioclase component, the composition of the Fe-Ti oxides, the occurence even of magnesiochromite crystals within tuffs of rhyoloitic-dacitic composition can be accommodated under the effect of magma mixing procedures, more specifically in the Akrotiri case, of a mixing-mingling mechanism which involves two parts, a mantle derived, saturated mafic composition component and a silicic magma part, in relatively shallow crustal depths. Pyle et al (1988) were among the first, using U-Th isotopic data, to suggest mixing between a crystal mush and a magma in an andesite from the island of Santorini, in the Aegean arc. The lava contains crystal populations from two sources of distinct thorium isotope composition: one from a basic cumulate; the other phenocrysts from a dacite magma.

Mixing procedures, such as the emplacement of andesite into a voluminous rhyolite magma in a mid-crustal magma chamber led to the explosive Kos Plateau Tuff super-eruption in the eastern part of the Aegean Arc (Pe-Piper and Moulton, 2008). Also, evidence of magma mixing for the precaldera deposits of Nisyros has been presented by Seymour and Vlassopoulos (1992). It is accepted that the injection of mafic magma into a magma reservoir of intermediate composition may trigger eruption due to the combined effects of increased mass, heat and volatile input (Sparks et al., 1977). The abundance of mafic enclaves in andesites and dacites from a number of arc volcanoes, and disequilibrium textures in the host lavas, provide support for this model (Zellmer et al., 2003).

Nevertheless, it has been proved that the understanding of the petrogenetic history of some intermediate arc magmas appears to be rather complicated. Recently, Bailey et al. (2009) have suggested, by using elemental and $\mathrm{Sr}-\mathrm{Nd}-\mathrm{Pb}$ isotopic data, that three main (and a fourth, less prominent) magmatic series with sub-parallel trace element patterns for basalts can be distinguished in northern Santorini. The long-lived histories of the three main magmatic series imply repetitive melting of isolated mantle regions, ascent of magmas through independent feeder systems, and their residence in separate crustal magma chambers. It becomes apparent that further investigation of the elemental, mainly of traces, and of the isotopic characteristics of the entire Akrotiri volcanic suite can only unfold a more detailed of the magma evolution and eruption mechanism of the earliest volcanic centre of Santorini.

\section{Acknowledgments}

The author has been always greatful to the Academic, Technical and Clerical Staff of the Geology Department of Leicester University for their kind host and constant support for almost two decades now. For their master knowledge and their valuable help with the analytical work and the data handling and interpretation, Rob Wilson, Nick Marsh, Rob Kelly, Rod Branson and Collin Cunningham should be specially mentioned. On 14/07/2007 Dr. Tim Brewer was suddenly lost for ever. I shall 
always remember and be grateful to Tim for proposing and setting up a Fellowship, so I can be able to continue my work in Leicester. Part of this work has been carried out under the inspired supervision and guidance of Prof Ansel Dunham. Ansel is always be remembered, thanked and honored by his numerous $\mathrm{BSc}, \mathrm{MSc}$ and $\mathrm{PhD}$ students around the world.

\section{References}

Anderson, A.T., 1983. Oscillatory zoning of plagioclase: Nomarski interference microscopy of etched polished sections. American Mineralogist 68, 125-129.

Bailey, J.C., Jensen, E.S., Hansen, A., Kann, A.D.J., \& Kann, K., 2009. Formation of heterogeneous magmatic series beneath North Santorini, South Aegean island arc. Lithos 110, 20-36.

Bathrellos,G.D., Vasilatos, C., Skilodimou, H.D., \& Stamatakis, M.G., 2009. On the occurrence of a pumice-rich layer in Holocene deposits of western Peloponnesus, Ionian Sea, Greece. A geomorphological and geochemical approach. Central European Journal of Geosciences 1, 19-32

Clark, A.H., Pearce, T.H., Roeder, P.L., \& Wolfson, I., 1986. Oscillatory zoning and other microstructures in magmatic olivin and augite: Nomarski interference contrast observations on etched polished surfaces. American Mineralogist 71, 734-741.

Davis, E., Gartzos, E., \& Dietrich, V.J., 1998. Magmatic Evolution of the Pleistocene Akrotiri Volcanoes. In Casale, R. et al (eds), Proceedings of the 2nd workshop, "The European Laboratory Volcanoes", Santorini, 2-4 May 2-4 1996, 49-68.

Dietrich, V.J., Davis, E., \& Gartzos, E., 1998. Amphibole in rhyodacites and dacites from the Akrotiri volcanoes and the complexities of discontinuous fractional crystallization. In Casale, R. et al (eds), Proceedings of the 2nd workshop, "The European Laboratory Volcanoes", Santorini, 2-4 May 2-4 1996, 69-80.

Druitt, T.H., Edwards, L., Mellors, R.M., Pyle, D.M., Sparks, R.S .J., Lanphere, M., Davies, M., \& Barriero, B., 1999. Santorini Volcano, Geological Society, London, Memoirs, 19, 165pp.

Fouque, F., 1879. Santorin et ses Eruptions, Paris, G. Masson, 440pp.

Huijsmans, J.P.P., Barton, M., \& Salters, V.J.M., 1988. Geochemistry and evolution of calc-alkaline volcanic complex of Santorini, Aegean Sea, Greece. Journal of Volcanology and Geothermal Research 34, 283-306.

Karberg, S., \& Burton, M., 2006. Oxygen fugacities of mafic magmas erupted in the Santorini volcanic field, Aegean Sea, Greece. GSA Abstracts with Programs 38 (7), Paper No. 183-13, p. 447.

Kitsopoulos, K.P., 1995. The mineralogy, geochemistry, physical properties and possible industrial applications of volcanic zeolitic tuffs from Santorini and Polyegos islands, Greece, University of Leicester, $\mathrm{PhD}$ Thesis, 442pp.

Kitsopoulos, K.P., 1996. Zeolitization of the Akrotiri pre-caldera pyroclastics from Santorini island, Greece. Implications for existing zeolitization models as applied with volcaniclastic materials, GSA Abstracts with Programs 28 (7), A-104.

Kitsopoulos, K. P., Scott, P.W., Jeffrey, C.A., and Marsh, N.G,, 2001. The mineralogy and geochemistry of zeolite-bearing volcanics from Akrotiril (Santorini island) and Polyegos (Milos group of islands) Greece. Implications for geochemical classification diagrams. Bulletin of the Geological Society of Greece XXXIV/3, Proceedings of the 9th International Congress, Athens, 859-865.

Mitropoulos, P., \& Tarney, J., 1992. Significance of mineral composition variations in the Aegean Island Arc, Journal of Volcanology and Geothermal Research 51, 283-303.

Nicholls, I.A., 1971. Petrology of Santorini volcanic rocks. J Petrol. 12, 67-119.

Pe-Piper, G, \& Piper, D.J.W, 2005. The South Aegean active volcanic arc: relationships between mag- 
matism and tectonics. Developments in Volcanology 7, 113-133.

Pe-Piper, G, \& Mourton, B. 2008. Magma evolution in the Pliocene-Pleistocene succession of Kos, South Aegean arc, Greece. Lithos 106, p. 110-124

Pichler, H., \& Kussmaul, S., 1972. The calc-alcaline volcanics rocks of the Santorini Group (Aegean Sea, Greece), Neues Jahrbuch Mineralogie Abhandlungen, 116: 268-307N.

Pyle, D.M., Ivanovich, M., \& Sparks, R.S.J., 1988. Magma-cumulate mixing identified by U-Th disequilibrium dating. Nature 331, 157-159.

Seymour, K.St., Vlassopoulos, D., Pearse, T.H., \& Rice, C.,1990. The record of magma chamber process in plagioclase phenocryst at Thera volcano, Aegean volcanic arc, Greece. Contributions to Mineralogy and Petrology. 104, 73-84.

Seymour, K.S., Vlassopoulos, D., 1992. Magma mixing at Nisyros volcano, as inferred from incompatible trace-element systematics. Journal of Volcanology and Geothermal Research 50, 273-299.

Sparks, R.S.J., Sigurdsson, \& H., Wilson, L., 1977. Magma mixing: a mechanism for triggering acid explosive eruptions. Nature 267, 315-318.

Tsolis-Katagas, P., \& Katagas, C., 1989. Zeolites in Pre-Caldera pyroclastic rocks of the Santorini Volcano, Aegean Sea, Greece. Clays and Clay Minerals 37, 497-510.

Winchester, J. A., and Floyd, P.A., 1977. Geochemical discrimination of different magma series and their differentiation products using immobile elements. Chemical Geology. 20, 325-343.

Zellmer, G.F., Sparks, R.S.J., Hawkesworth, C.J., \& Wiedenbeck, M., 2003. Magma emplacement and remobilization timescales beneath Montserrat: insights from $\mathrm{Sr}$ and $\mathrm{Ba}$ zonation in plagioclase phenocrysts. Journal of Petrology 44, 1413-1431. 